\section{Penetration and Sorption of Methyl Bromide in Returnable Plastic Containers}

\author{
Michael R. Boersig, \\ Preston Hartsell, and \\ Joseph Smilanick ${ }^{2}$
}

Additional index words. fumigation, RPC, grapes, sulfur dioxide, quarantine treatment

Summary. Methyl bromide (MB) penetration rates, sorption levels, and concentration.time (CT) products were compared in returnable plastic containers (RPCs) and corrugated grape boxes (CGBs). During a 2.5-hour fumigation, sorption of methyl bromide in RPCs and CGBs was $9.8 \%$ and $18.1 \%$, respectively. The lower sorption in RPCs increased the exposure of grapes (Vitis vinifera) to MB. Equilibrium concentrations of $\mathrm{MB}$ (concentrations that had stabilized) in RPCs and CGBs were 68.2 and $59.2 \mathrm{~g} \cdot \mathrm{m}^{-3}(4.26$ and $3.70 \mathrm{lb} / 1000 \mathrm{ft}^{3}$ ) respectively. The CT products in RPCs and CGBs were 170.5 and $147.6 \mathrm{~g} \cdot \mathrm{h}^{-1} \cdot \mathrm{m}^{-3}(10.66$ and $\left.9.19 \mathrm{lb} / \mathrm{h} / 1000 \mathrm{ft}^{3}\right)$, respectively, and far below phytotoxic concentrations according to the U.S. Department of Agriculture schedule.

$\mathrm{R}$ ecently, there has been a proliferation of new pack aging for the fresh produce industry driven by new methods of distributing and merchandising fruits and vegetables. The pooling of RPCs is a concept that was imported to the United States on a small scale in the late 1990s, and has expanded to a volume of about 60 million containers shipped in 2001 (Returnable Pallet and Container Coalition, personal communication). The first commercial shipments of table grapes and stone

Dried Fruit Association, 1855 South Van Ness, Fresno, CA 93721.

${ }^{1}$ CHEP USA, 2661 Cascade Trail, Cool, CA 95614.

${ }^{2}$ USDA ARS, San Joaquin Valley Agricultural Sciences Center, 9611 S. Riverbend Avenue, Parlier, California 93648 fruit (Prunus spp.) in RPCs from Chile to the United States took place in 2001 (unpublished data). It can be expected that imports in RPCs will continue to increase.

The USDA Animal and Plant Health Inspection Service (APHIS) requires $\mathrm{MB}$ fumigation of imported Chilean plant products. In addition to this quarantine requirement, grapes packed in the U.S., Mexico, and Chile are routinely fumigated with sulfur dioxide $\left(\mathrm{SO}_{2}\right)$ to control fungal diseases (Luvisi et al., 1992). The appropriate conditions for fumigation with $\mathrm{MB}$ combined with $\mathrm{SO}_{2}$ in traditional packaging have been worked out and used routinely for many years (Phillips et al., 1984; Smilanick et al., 2000). It is also well known that different types of packaging have different sorption characteristics in relation to fumigation gases, including $\mathrm{MB}$ (Harris et al., 1984; Harvey et al., 1988). The difference between RPCs and CGBs in relation to $\mathrm{MB}$ sorption has not previously been investigated. We compared $\mathrm{MB}$ penetration rates, sorption levels, and CT products in RPCs and CGBs.

\section{Materials and methods}

Plants. 'Thompson Seedless' table grapes were harvested from commercial vineyards in Tulare County, Calif., on 24 Aug. 2001 and were packed in perforated plastic bags.

Packaging components. All experimental containers had internal packaging that conformed to common practice for Chilean exports, including 1) low-density transparent perforated plastic bag (enclosing all other components); 2) four sheets of tissue paper laid under and folded over the grapes from all four sides; 3 ) one absorbent dimpled paper pad; 4 ) grapes in perforated polyethylene bags [12 bags, $8.2 \mathrm{~kg}$ (18 lb) per container]; 5) one $\mathrm{SO}_{2}$ generator pad (Proem, Santiago, Chile) wrapped in tissue paper; 6) one absorbent dimpled paper pad; and 7) two adhesive stickers used to hold the folded top of the main bag closed. Three separate container options were used 1) CGBs packed in Chilean style (about $5 \%$ side wall ventilation); 2) RPCs packed in Chilean style (about $15 \%$ side wall ventilation); and 3) RPCs packed in Chilean style plus an excelsior pad and a three-layer absorbent towel (about 15\% side wall ventilation).

Fumigation Procedure. The 

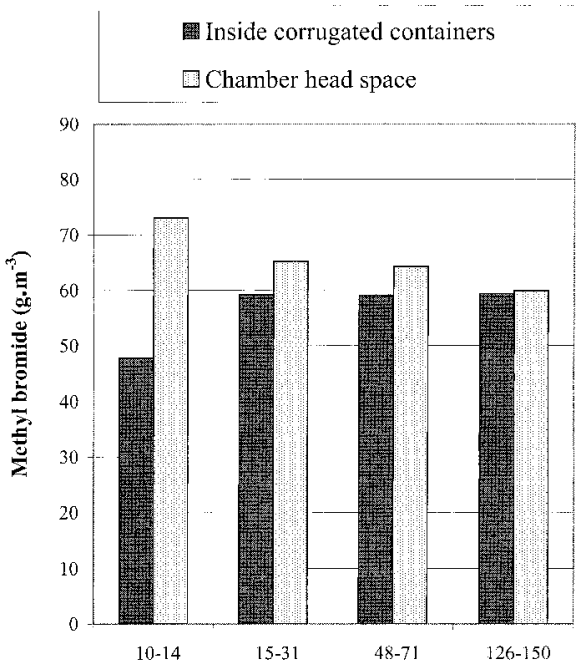

Time intervals (min after injection began)

Fig. 1. Exposure of methyl bromide to 'Thompson Seedless' grapes packed in corrugated cardboard boxes. First corrugated value and all head space values represent individual gas samples. Corrugated data after $15 \mathrm{~min}$ are pooled values of five or six samples; $1 \mathrm{~g} \cdot \mathrm{m}^{-3}=0.0625 \mathrm{lb}$ / $1000 \mathrm{ft}^{3}$.

three container types were fumigated sequentially in a $540 \mathrm{~L}\left(19 \mathrm{ft}^{3}\right)$ capacity chamber. The chamber was equipped with an air circulation fan that ran continuously during exposure and aeration. The fumigation procedures and techniques were performed as described by Smilanick et al. (2000), Hartsell et al. (1986), and Tebbets et al. (1983). The chamber met or exceeded performance requirements for quarantine treatments by USDAAPHIS.

The fumigation schedule was based on the USDA-APHIS requirements for Chilean import of table grapes(USDA, 1998). Specifically, the treatment was $64.0 \mathrm{~g} \cdot \mathrm{m}^{-3}$ methyl bromide $\left(4 \mathrm{lb} / 1000 \mathrm{ft}^{3}\right)$ for $2.5 \mathrm{~h}$ at 8.9 to $9.4{ }^{\circ} \mathrm{C}\left(48\right.$ to $\left.49^{\circ} \mathrm{F}\right)$. $\mathrm{MB}$ and $\mathrm{SO}_{2}$ were introduced to the chambers in gas form from a lecture bottle and small cylinder using gas-tight syringes (500 to $1000 \mathrm{~mL}$ ).

Eight CGBs or 8 RPCs were placed in the chamber in two stacks of four. The corrugated boxes and RPCs displaced about $47 \%$ and $41 \%$ of the chamber volume, respectively. Gas samples were taken through $86.4-\mathrm{cm}$ (34-inch) lengths of Teflon tubing (Stranco Products, Schaumburg, Ill. ) with inner and outer diameters of 1.5 and $4 \mathrm{~mm}$ (0.06 and 0.16 inch $)$, respec-

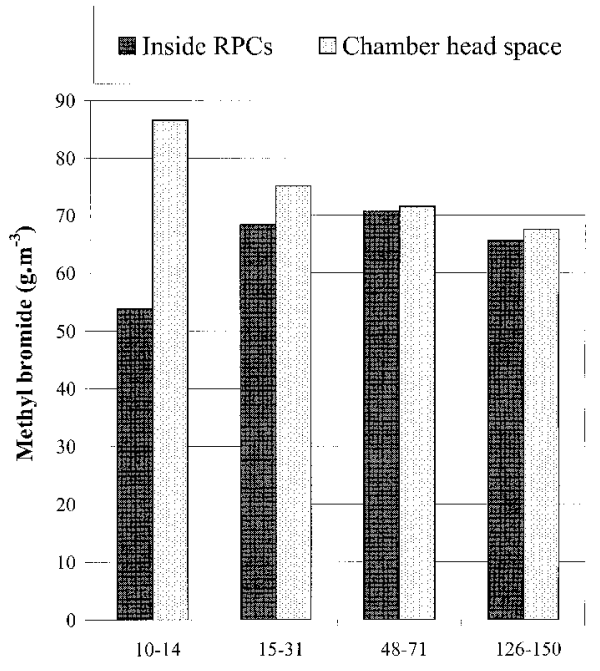

Time intervals (min after injection began)

Fig. 2. Exposure of methyl bromide to 'Thompson Seedless' grapes packed in returnable plastic containers (RPCs). First RPC value and all head space values represent individual gas samples. RPC data after 15 min are pooled values of five or six samples; $1 \mathrm{~g} \cdot \mathrm{m}^{-3}=0.0625 \mathrm{lb} / 1000 \mathrm{ft}^{3}$. inserted into the center of the middle cluster of grapes in the lower three containers within each stack. The tubing exited the side of the chamber through Teflon-lined neoprene stoppers. Outside the chamber, sample lines were fitted with $5.1-\mathrm{cm}$ (2-inch) lengths of surgical tubing and a hose clamp for gas withdrawal. A separate valve opening was used for sampling MB from the chamber head space. Gas samples were taken from each of the six containers sequentially following $\mathrm{MB}$ introduction, which took about $10 \mathrm{~min}$. Time between samples was about 2 to $3 \mathrm{~min}$. This procedure was repeated again after about $30 \mathrm{~min}$ and near the end of exposure of $2.5 \mathrm{~h}$.

Concentrations of $\mathrm{MB}$ and $\mathrm{SO}_{2}$ tively. One end of the Teflon tubing was

were determined by means of a gas chromatograph (model 1200; Fisher, Pittsburgh, Pa.) using thermal conductivity detection. In order to flush the tubing, about $7 \mathrm{~mL}(0.24 \mathrm{fl} \mathrm{oz})$ of gas was extracted and disposed of before each sampling. After flushing each set of tubing, samples of about $25 \mathrm{~mL}$ $(0.85 \mathrm{fl} \mathrm{oz})$ were collected and introduced to the GC via an integral gas sampling valve with $1 \mathrm{~mL}$ loop. Temperatures of the column, detector, and valve were $150{ }^{\circ} \mathrm{C}\left(302.0^{\circ} \mathrm{F}\right), 170^{\circ} \mathrm{C}$ $\left(338.0^{\circ} \mathrm{F}\right)$, and $170^{\circ} \mathrm{C}$, respectively. The helium carrier gas flow rate through the $1.8-\mathrm{m}$-long $(5.9-\mathrm{ft})$ by 4 mm-diameter (0.16-inch) Poropak Q column (Millipore Corp., Bedford, Mass.) was $25 \mathrm{~mL} \cdot \mathrm{min}^{-1}(0.85 \mathrm{fl} \mathrm{oz} /$ $\mathrm{min})$. The retention times of $\mathrm{SO}_{2}$ and $\mathrm{MB}$ were 0.08 and $1.9 \mathrm{~min}$, respectively.

An analysis of variance was applied on MB concentrations and CT products after equilibrium was established (the final $2.25 \mathrm{~h}$ of fumigation for CGBs and RPCs; the final $2 \mathrm{~h}$ of fumigation for RPCs + excelsior pad and toweling) using 17 or 12 replications per packaging configuration. Means were separated by Student's $t$ test at $P=0.05$.

\section{Results}

Diffusion of $\mathrm{MB}$ into corrugated boxes and RPCs is illustrated in Figs. I and 2 . Since it took 9 to $10 \mathrm{~min}$ to inject $\mathrm{MB}$ into the chamber, readings before $10 \mathrm{~min}$ were not made. The two earliest sets of readings from the chamber headspace and from inside the first boxes ( 10 to 14 min in Figs. 1 and 2) show that equilibrium had not yet been reached in either the corrugated boxes or the RPCs. The head space readings at the earliest point in the corrugated test, and throughout the RPC tests, were higher than the applied dose of $64 \mathrm{~g} \cdot \mathrm{m}^{-3}$ of methyl

Table 1. Methyl bromide (MB) sorption, concentration, and concentration time $(\mathrm{CT})$ products of corrugated boxes and returnable plastic containers (RPCs). Numbers followed by different letters within a column are significantly different at the $95 \%$ confidence level.

\begin{tabular}{lccc}
\hline Container & \multicolumn{2}{c}{$\begin{array}{c}\text { MB level at } \\
\text { CT product }\end{array}$} \\
\hline Corrugated pack & 18.1 & $59.2 \mathrm{a}$ & $147.6 \mathrm{a}$ \\
RPC Pack & 9.8 & $68.2 \mathrm{~b}$ & $170.5 \mathrm{~b}$ \\
RPC Pack + Excelsior pad and toweling & 14.7 & $67.5 \mathrm{~b}$ & $166.3 \mathrm{~b}$
\end{tabular}

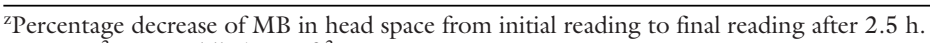

${ }^{\mathrm{y}} 1.0 \mathrm{~g} \cdot \mathrm{m}^{-3}=0.0625 \mathrm{lb} / 1000 \mathrm{ft}^{3}$.

${ }^{\mathrm{x}} 1.0 \mathrm{~g} \cdot \mathrm{h}^{-1} \cdot \mathrm{m}^{-3}=0.0625 \mathrm{lb} / \mathrm{h} / 1000 \mathrm{ft}^{3}$. 
bromide. This is indicative of chamber-volume displacement by the containers, internal packaging, and grapes.

The MB concentration inside both box types reached equilibrium after about $15 \mathrm{~min}$. The slight increase in $\mathrm{MB}$ concentration inside RPCs at 4 to 71 min was not statistically higher than the level at 15 to $31 \mathrm{~min}$. Columns in Figs. 1 and 2, which indicate MB concentrations inside containers at 15 to $31 \mathrm{~min}$ and later, represent averages of gas samples from five or six separate boxes. All columns representing chamber head space are from single gas samples.

There was a substantial difference in sorption due to box type (Table 1 ). As a result of this difference in sorption, the equilibrium gas concentrations and the CT products were higher inside RPCs than inside the corrugated boxes (Table 1). The differences in equilibrium gas concentrations and CT products were statistically significant at the 95\% confidence level.

When the standard Chilean pack in the RPC was supplemented with an excelsior pad and a sheet of three-ply absorbent paper toweling, MB sorption rose from $9.8 \%$ to $14.7 \%$ (Table 1). The change in internal $\mathrm{MB}$ concentration and CT product as a result of the supplemental packaging was not statistically significant.

\section{Discussion}

The difference in sorption observed between container types is not surprising, since the RPCs are made of polypropylene, which does not absorb MB. Because of this difference, grapes fumigated in RPC packages may be exposed to larger $\mathrm{MB}$ doses than those fumigated in corrugated boxes. The $\mathrm{MB}$ dosage used in these studies was $64 \mathrm{~g} \cdot \mathrm{m}^{-3}$, the highest allowable, according to the USDA-APHIS schedule for quarantine treatment of table grapes from Chile (USDA, 1998). The USDA-APHIS schedules are made on the basis of an empty chamber with an allowance for a volume load of $80 \%$ or less. This means that the boxes themselves are allowed to occupy up to $80 \%$ of the chamber space, resulting in gas concentrations that can be considerably higher than the prescribed doses, especially before $\mathrm{MB}$ sorption has taken place. Fumigation under a tarpaulin is subject to more variability than that in a chamber, because of leakage from a tarpaulin. A second application of gas is allowed under a tarpaulin if measurements of gas during fumigation deem it necessary. The maximum MB concentration that was recorded inside an RPC during this study was 72 $\mathrm{g} \cdot \mathrm{m}^{-3}\left(4.5 \mathrm{lb} / 1000 \mathrm{ft}^{3}\right)$ with a chamber load of $41 \%$ and a sorption of $9.8 \%$. This level is far below what is considered potentially phytotoxic according to the USDA schedule (USDA, 1998). When a technician is determining whether to reapply gas under a tarpaulin, however, the lower sorption associated with RPCs will need to be taken into consideration.

\section{Literature cited}

Harris, C.M., J.M. Harvey, and D.C. Fouse. 1984. Penetration and retention of methyl bromide in packaged table grapes. Amer. J. Enol. Viticult. 35:5-8.

Hartsell, P.L., H.D. Nelson, J.C. Tebbets, and P.V.Vail. 1986. Methyl bromide treatments for pistachio nuts to decrease residues and control navel orangeworm, Amyelois transitells (Lepidoptera: Pyralidae). J. Econ. Entomol. 79:12991302.

Harvey, J.M. , C.M. Harris, T.A. Hanke, and P.L. Hartsell. 1988. Sulfur dioxide fumigation of table grapes: relative sorption of $\mathrm{SO}_{2}$ by fruit and packages, $\mathrm{SO}_{2}$ residues, decay, and bleaching. Amer. J. Enol. Viticult. 39:132-136.

Luvisi, D., H. Shorey, J.L. Smilanick, J. Thompson, B.H. Gump, and J. Knutson. 1992. Sulfur dioxide fumigation of table grapes. Univ. Calif., Div. Agr. Natural Resources Bul. 1932.

Phillips, J.D. , R.K. Austin, D.C. Fouse, and D.A. Margosan. 1984. The quality of early-season table grapes fumigated with methyl bromide and sulfur dioxide. HortScience 19:92-93.

Smilanick, J.L., F. Mlikota, P.L. Hartsell, J.S. Muhareb, and N. Denis-Arrue. 2000. The quality of three table grape varieties fumigated with methyl bromide at doses recommended for control of mealybugs. HortTechnology 10:159-162.

Tebbets, J.S. , P.L. Hartsell, H.D. Nelson, and J.C. Tebbets. 1983. Methyl bromide fumigation of tree fruits for control of the Mediterranean fruit fly: Concentrations, sorption and residues. J. Agr. Food Chem. 31:247-249.

U.S. Department of Agriculture. 1998. Code of Federal Regulations. Title 7 Agriculture, Chapter III, Animal and Plant Health Inspection Service, Part 319. Foreign Quarantine Notices 266-267.
Rain Protective

Covering of Sweet Cherry

Trees-Effects of Different Covering Methods on Fruit Quality and Microclimate

\author{
J. Børve, ${ }^{1}$ E. Skaar, ${ }^{2}$ L. Sekse ${ }^{3}$ \\ M. Meland, ${ }^{3}$ and E. Vangdal ${ }^{3}$
}

Additional index words. Prunus avium, protected cultivation, fruit cracking, fruit decay

Summary. Three different rain protective covering methods for sweet cherry (Prunus avium) trees were tested with uncovered trees as control. The covers were a pitched cover mounted permanently, a similar cover mounted only when raining, and a permanent umbrella type enveloping the top and sides of single trees. Covers were mounted 3 weeks before and throughout the harvest period in two seasons with different weather conditions. All three covering methods increased the amount of marketable fruit from 54\% on uncovered to $89 \%$ on covered trees in mean of 2 years. Fruit from umbrella covered trees had lower soluble solid content, lower juice color and lower ripeness compared with fruit from all other trees, reflecting the different microclimate in these trees such as frequently higher maximum temperatures and greater vapor pressure. The two pitched covers produced no significant changes in microclimate or internal fruit quality compared with uncovered trees.

This experiment was the basis for a MS thesis at Norwegian Agricultural University, and the first author is indebted to the advisor, Sigbjørn Vestrheim. We also thank A. Stensvand for critical review of the manuscript and Geir Olav Guddal for drawing the different covering methods.

${ }^{1}$ Research scientist and corresponding author (jorunn.borve@planteforsk.no), Norwegian Crop Research Institute, Ullensvang Research Centre, 5781 Lofthus, Norway.

${ }^{2}$ Research scientist, Norwegian Crop Research Institute, Geophysical Institute, Allegaten 70,5007 Bergen, Norway.

${ }^{3}$ Head of department, Research scientist and Research scientist, Norwegian Crop Research Institute, Ullensvang Research Centre, 5781 Lofthus, Norway. 